\title{
The Remediation of Abandoned Iron Ore Mine Subsidence in Rockaway Township, New Jersey
}

Project Title

Report Type

Reporting Period

$\underline{\text { Principal Author }}$

$\underline{\text { Report Issued }}$

DOE Award \#

Submitted By
The Remediation of Abandoned Iron Ore Mine Subsidence in Rockaway Township, New Jersey

Semi-Annual Technical Progress Report

Start Date - September 29, 2000

End Date - March 29, 2001

Gary Gartenberg, P.E., P.P.

April 2001

DE-FC26-97FT975000

Mr. Steven Levinson, M.S., HO

Business Administrator

Rockaway Township

Sixty-Five Mt. Hope Road

Rockaway, New Jersey 07866-1699

Report Production By:

Gary Gartenberg, P.E., P.P.

Gartenberg, Associates, L.L.C.

P.O. Box 243

Convent Station, New Jersey 07961 


\section{$\underline{\text { Disclaimer }}$}

This report was prepared as an account of work sponsored by an agency of the United States Government. Neither the United States Government nor any agency thereof, nor any of their employees, makes any warranty, express or implied, or assumes any legal liability or responsibility for the accuracy, completeness, or usefulness of any information, apparatus, product, or process disclosed, or represents that its use would not infringe privately owned rights. Reference herein to any specific commercial product, process, or service by trade name, trademark, manufacturer, or otherwise does not necessarily constitute or imply its endorsement, recommendation, or favoring by the United States Government or any agency thereof. The views and opinions of authors expressed herein do not necessarily state or reflect those of the United States Government or any agency thereof. 


\begin{abstract}
This report represents the seventh Semi-Annual Technical Progress Report issued in connection with the subsidence remediation projects undertaken by Rockaway Township in Morris County, New Jersey. This report provides a summary of the major project work accomplished during this reporting period and contemplated for the subsequent reporting period. This report is issued as part of the project reporting provisions set forth in the Cooperators Agreement between the United States Government - Department of Energy, and Rockaway Township.
\end{abstract}

The purpose of the Cooperators Agreement is for the Department of Energy to provide technical and financial assistance in a coordinated effort with Rockaway Township to develop and implement a multi-phased plan to remediate ground stability problems associated with abandoned mining activity. Primarily during the 1800's, extensive iron ore mining and prospecting was undertaken in Rockaway Township, part of the Dover District Mining region in Morris County. The abandoned mining activity has resulted in public safety hazards associated with ground collapse and surface subsidence features evolving in both developed and undeveloped areas within Rockaway Township.

At the Green Pond Mine site at the Township Compost Storage Facility, research and preliminary design was performed during this reporting period toward development of the engineering plans and Technical Specifications for the remediation work.

At the White Meadow Mine site, the remediation project was conducted last reporting period by others, out of the responsibility of Rockaway Township under this Cooperators Agreement.

At the Mt. Hope Road subsidence, surface monitoring was conducted at the work area and adjacent areas after the January 2000 construction effort. 


\section{$\underline{\text { Summary }}$}

Research work and preliminary engineering design was conducted toward preparation of the remediation engineering design and Technical Specifications for the Green Pond Mines Project.

Monitoring of the Mt. Hope Road subsidence project occurred during this reporting period. No observations of adverse subsidence where noted at the area of concern. 
The Remediation of Abandoned Iron Ore Mine Subsidence in Rockaway Township, New Jersey
Semi-Annual Technical Progress Report DOE Award \# DE-FC26-97FT975000

Period Ending March 29, 2001

\section{Table of Contents}

Title Page 1

Disclaimer 2

Abstract 3

Summary 4

Table of Contents 5

Results and Discussion 6

Conclusions 8

Appendix 8 


\section{$\underline{\text { Results and Discussion }}$}

The following information provides the results of the major issues, work items and areas of investigation considered during the reporting period of this Technical Progress Report.

\section{General Project Communications and Fundamentals}

During this semi annual reporting period various communications and coordination occurred as was necessary in connection with the project work and Cooperators Agreement. Application for a no cost time extension of the current Cooperators Agreement was applied for and obtained from the Department of Energy during this reporting period.

Work occurred during this reporting period toward preparation of the semi-annual Technical Progress Report for the previous period for the United States Department of Energy on behalf of Rockaway Township in accordance with the requirements set forth in the Cooperators Agreement.

\section{White Meadow Mine - Project Status}

Remedial work at the White Meadow site was undertaken during the previous reporting period by the Property Owner, out of the purview of the Cooperators Agreement between Rockaway Township and the United States Department of Energy. This project is no longer included or monitored under this Cooperators Agreement.

\section{Green Pond Mines - Project Status}

During this reporting period, field work was conducted to monitor conditions at the Green Pond Mine site. Analysis of the historical data, research, and geophysical results continued toward finalization of the engineering remedial design and preparation of the project specifications.

\section{Mt. Hope Road - Project Status}

In January 2000, the remedial construction work was undertaken and completed at the Mt. Hope Road subsidence site which included the installation of a concrete safety plug/cap. Monitoring to date of surface conditions of the area of work and adjacent areas, has not observed any adverse surface conditions.

\section{General Remediation - Project Status}

Numerous hazards exist within Rockaway Township from abandoned mining activity. It is the Rockaway Township's intend to address other abandoned mining activity hazards on a priority basis under the Cooperators Agreement after completion of the Green Pond Mine project. 


\section{Subsequent Reporting Period Activity Plan}

It is anticipated that engineering plans and Technical Specifications for the remediation will be completed during the subsequent reporting period. The project will be bid and the primary remedial construction would be undertaken during this reporting period.

Depending on the final cost of the Green Pond Mines project, the balance of the financial assistance from the United States Department of Energy under this agreement would be applied toward addressing the numerous mining hazards which exist in Rockaway Township as a result of abandoned iron ore mining activity from 1800's. 
The Remediation of Abandoned Iron Ore Mine Subsidence in Rockaway Township, New Jersey
Semi-Annual Technical Progress Report DOE Award \# DE-FC26-97FT975000

Period Ending March 29, 2001

\section{Conclusions}

No additional field survey, completed research or design, or physical construction was undertaken during this reporting period. Consequently, no additional conclusions are set forth during this reporting period.

\section{$\underline{\text { Appendix }}$}

This Report does NOT contain an Appendix 